\title{
VIEWPOINT
}

\section{Working as a cardiologist in the USA}

\author{
Neal G Uren, Nicolas A F Chronos
}

There are several different reasons for cardiologists in training to spend a period of time in the United States of America in the context of work. This may be temporary in the case of a short sabbatical or travelling fellowship, where the recipient may travel to a centre with an particular area of expertise to study and learn a new or novel technique over a period of a few weeks. The period may be longer, for example one to two years, when a period of research or clinical training may be undertaken. The third context is permanent, where a decision may have been made to emigrate to the USA to work without initial intent to return. In general, the second option is the most frequent, and this article is intended to act as a guide for cardiologists in training who are considering such a move.

\section{Timing}

The decision to move to the USA is usually made at defined periods in the career of a junior doctor specialising in cardiology. The first opportunity is usually after preregistration when, for personal reasons, the individual may wish to emigrate to the USA in an open ended fashion to join relatives, through marriage, or simply through a desire to live in another country. This requires application to a residency programme in the specialty of choice and is, of course, the best time to consider a permanent move, as the individual becomes board certified in internal medicine and then in cardiovascular medicine.

With the introduction of the unified training grade for specialist training in cardiology (specialist registrar), ${ }^{1}$ there may still be the opportunity to work in the USA. This could be before entry to the grade, although the need to return to the United Kingdom for interviews for the training grade position would hamper this approach. It is envisaged that once in the training grade, one to two years should still be spent pursuing research interests. ${ }^{2}$ This second opportunity would arise at the time of intended entry into a period of research (previously after a clinical registrar job), which would now be midway through the specialist registrar grade. This requires funding from a grant awarding body aware of the fact that the recipient is likely to carry out the research
The third opportunity would be after completion of training, which was previously during the period of a senior registrar job. The latter was the most secure choice, as regional health authorities or NHS Trust hospitals would hold the post during the sabbatical and appoint a locum senior registrar. With the introduction of the specialist registrar grade, this period now occurs after receiving the certificate of completion of specialist training (CCST) and before securing a consultant post.

Irrespective of the timing of the intended sabbatical, it is imperative that trainees should clear the proposal with the local specialty training committee which would advise the individual on the appropriate clinical skills that may be needed during the sabbatical and the nature of any research intended. It is also essential that trainees discuss any proposed clinical work done in the USA with the specialist advisory committee in cardiovascular medicine with respect to accreditation towards the CCST. These consultations are essentially facilitative and not intended to block any proposed sabbatical, but to ensure that the time spent in the USA is as productive and appropriate to each individual as possible.

\section{Funding}

There is a limited number of ways whereby one can receive funding for a sabbatical move $\bar{N}$ to the USA. First, honorary lecturers who are recipients of prolonged grants such a Medical Research Council clinician scientist award or a $\mathrm{\omega}$ British Heart Foundation clinical scientist $\underset{2}{2}$ award over a period of several years may take $\varphi$ this funding to a unit of their choice in the $\bar{D}$ USA. Such moves usually occur between units with similar interests where collaboration is envisaged, or they may occur because of a perceived need to learn a new technique in the fields of basic science research, molecular biology, or molecular genetics.

Secondly, one can apply for either an MRC or Wellcome travelling fellowship, to an independent grant awarding body or, most com- 흠 monly, to the British Heart Foundation, which awards a finite number of international fellowships each year. These fellowships require a written grant proposal along with written support of the supervising consultants in the USA away from the United Kingdom. 
and the United Kingdom. It is possible to retrieve a list of charities and grant awarding bodies in a register held at any public library.

The third method of generating income is to apply for funding from the institution to which one is intending to go. In the USA, this usually means that one has to apply to a fellowship programme in cardiovascular medicine. The advantage of this approach is that if successful, one enters a fellowship programme of a US hospital with fewer American doctors entering fellowships with a strong research bias. However, there are several disadvantages. Fellows in research receive an annual gross salary of around $\$ 29000$ ( $\sim 19300$ ), rising to $\$ 34000$ $(\sim £ 22700)$ in a clinical fellowship, which is less than a basic salary without additional duty hours [overtime] if paid by a UK grant awarding body. One is usually committed to spending a minimum of two years in such a post, normally split between clinical work and research in each year, which can be a problem if one has taken leave in the form of a secondment with a need to return to the United Kingdom before the end of the two years. US fellows are roughly equivalent to the midpoint of the specialist training grade in terms of experience and would be most appropriate for specialist registrars at a similar point of their careers.

\section{Taxation}

It is usually standard practice for salaries received from the Wellcome trust or charities such as the British Heart Foundation to continue to be paid into the grantee's current account at home. A reciprocal tax arrangement exists between the USA and the United Kingdom such that one cannot be taxed in both countries simultaneously. Because the nature of the sabbatical is educational, recipients are not responsible for paying income tax in the United Kingdom as long as they are out of the country for more than five sixths of the year from the start of the period abroad. This arrangement is valid and not dependent on the individual being away during the entire tax year from 5 April, as often reported. It is implicit in this arrangement that you are out of the United Kingdom (not necessarily in the USA) on the anniversary of the day on which you initially left.
Once in the USA for more than two years, you become liable for US federal and state tax in the third year of stay. If any additional work is done not directly related to the sabbatical, such as lecturing, you will be liable to federal tax on that amount.

It is essential to contact the Inland Revenue well in advance of the trip. The Inland Revenue issues a pamphlet to advise of these matters available directly from the local tax office (Going to Work Abroad?-Personal Taxpayer Series IR58).

\section{Visa regulations}

The type of working visa required is determined by the host institution in the USA. There are two basic types which are relevant to junior doctors: (1) the J1 (exchange visitor) visa, and (2) the $\mathrm{H}-1 \mathrm{~B}$ visa (see the table). The J1 visa is the standard visa for a so called educational exchange. The visa issued is dependent on the wishes of the US institution and the supervising consultants with whom one is working. If much clinical work is anticipated, the appropriate visa to have is a $\mathrm{J} 1$ (clinical) visa. It is more time consuming to obtain this visa than the J1 (research) for administrative reasons. To obtain a J1 (clinical) visa, one requires the United States medical licensing examination (USMLE), set and administrated by the Educational Commission for Foreign Medical Graduates (ECFMG). If you envisage a prolonged move to the USA, step 3 of the USMLE, which is the final licensing examination, should also be done. Irrespective of whether you speak English as a native language, an English test is required to validate this certificate. This test, when repeated, revalidates the ECFMG certificate for two years at a time.

Visa applications are made by the US institution twice yearly towards the end of July and November. It is imperative that all relevant documents are submitted to the host institution around six weeks before these deadlines. It is possible to go to the USA on a tourist visa for a maximum stay of 90 days, after which time you have to return to the United Kingdom with an IAP-66 form and have the appropriate exchange visa added your passport at the United States Embassy.

Non-immigrant working visas for doctors

\begin{tabular}{|c|c|c|c|c|}
\hline Visas & Description & Conditions & Family members & Conversion to permanent residence \\
\hline $\mathrm{J} 1$ & $\begin{array}{l}\text { A training visa which } \\
\text { permits work within } \\
\text { the USA as an exchange } \\
\text { Program Visitor. }\end{array}$ & \multirow{3}{*}{$\begin{array}{l}\text { At the discretion of } \\
\text { ECFMG and the } \\
\text { Immigration and } \\
\text { Naturalization Service } \\
\text { (INS), renewable for up } \\
\text { to } 7 \text { years. }\end{array}$} & \multirow{3}{*}{$\begin{array}{l}\text { Eligible to apply for an } \\
\mathrm{J} 2 \text { visa for spouse } \\
\text { and children. Spouse } \\
\text { may work on this visa } \\
\text { after permission from } \\
\text { the INS. }\end{array}$} & \multirow{3}{*}{$\begin{array}{l}\text { If you have been paid by your home } \\
\text { government or the US government } \\
\text { or if on a special skills list (medical } \\
\text { doctors in particular), you are subject } \\
\text { to the two year home residency } \\
\text { requirement before returning on an } \\
\text { H-1B visa. In general, a waiver is } \\
\text { only granted if working for a US } \\
\text { government agency or if under } \\
\text { political persecution at home. }\end{array}$} \\
\hline - Clinical & $\begin{array}{l}\text { The visa holder may } \\
\text { perform clinical tasks } \\
\text { under supervision. }\end{array}$ & & & \\
\hline - Research & $\begin{array}{l}\text { The visa holder may } \\
\text { undertake clinical } \\
\text { research but not clinical } \\
\text { tasks. }\end{array}$ & & & \\
\hline H-1B & $\begin{array}{l}\text { A work permit } \\
\text { (temporary worker) } \\
\text { which allows a } \\
\text { professional employee } \\
\text { to come to the USA to } \\
\text { do professional work. }\end{array}$ & $\begin{array}{l}\text { Issued for up to three } \\
\text { years then extended up } \\
\text { to a total of six years. }\end{array}$ & $\begin{array}{l}\text { Eligible to apply for an } \\
\text { H4 visa for spouse and } \\
\text { children which allows } \\
\text { travel and school } \\
\text { attendance but not } \\
\text { work. }\end{array}$ & $\begin{array}{l}\text { Possible to apply for a green card } \\
\text { which allows a person to live and } \\
\text { work in the USA permanently. } \\
\text { Sponsorship from a US employer is } \\
\text { required (although a search must be } \\
\text { made for an equivalent US worker). }\end{array}$ \\
\hline
\end{tabular}


There are several documents to be submitted to the fellowship co-ordinator at the host institution. These are (1) a valid ECFMG certificate, (2) a letter from the Department of Health in Leeds assuring the host institution that sufficient jobs are available in cardiology in the United Kingdom to assure the fellow's return after the sabbatical, and (3) a certificate of good medical standing from the General Medical Council. After the visa deadline date, a certificate of eligibility for exchange visitor (J1 visa) status (form IAP66) is issued by the ECFMG and forwarded to the individual by the host institution (a separate form is necessary for family members). An appointment should be made by telephone for a non-immigrant visa to the United States embassy or consulate. One may attend in person or apply by post allowing a period of three weeks for the visa to be issued.

The $\mathrm{H}-1 \mathrm{~B}$ visa is more difficult to obtain as it permits the individual to apply for a green card or permanent residence status. Experience has shown that the most effective (but costly) way to obtain a green card is to employ an immigration lawyer in the USA. In former times, if the individual had $\mathrm{J} 1$ status and wished to convert to $\mathrm{H}-1$ status, a waiver on the two year home residency requirement of the J1 visa (table) was achieved through working in a Department of Veterans Affairs hospital in a clinical post for at least two years. However, this option has become increasingly difficult in many states. More information on visa requirements is available on the Internet at <http://www.immigration.com $>$.

\section{Acclimatisation in the USA}

After arrival, there are a few tasks that should be done at the earliest opportunity:

\section{SOCIAL SECURITY NUMBER AND BANKING}

All legal documents require a social security number which is also necessary for opening a bank account and obtaining a driving licence. This may be done at an office of the Department of Social Security. The easiest means of transferring money from the United Kingdom is to open a current account at a local bank. It is worth choosing a bank which has many branches in the town, city, or state in which you are working. It is possible to use a UK credit card in the USA after notifying a change of address.

\section{DRIVING LICENCE}

In the USA, a driving licence is used as a identification card and cheque guarantee because of the picture identification. You should apply to the local office of the Department of Motor Vehicles for a written test appointment (multiple choice questionnaire). Each state issues a driving handbook from which the questions are derived. Not all states require a subsequent "practical" driving test.

\section{HEALTH AND DENTAL INSURANCE}

It is important to have health insurance in the event of illness or accident. In most cases, the host institution will suggest an appropriate health care plan, often with a large health maintenance organisation (HMO). It is common for the host institution to pay for the insurance of the individual and subsidise the family members, significantly reducing the overall cost of health care insurance (usually a minimum of $\$ 100$ per month). Dental care is expensive in the USA. It is worth having any dental problems treated before departure, with the option of subscribing to a dental care plan in the USA to reduce the cost of emergency dental care if needed.

\section{ACCOMMODATION}

The fellowship coordinator will be able to send a list detailing the types of property avail- $\overrightarrow{0}$ able for renting and the approximate costs. As well as scanning the local newspaper for properties to rent, it is worth checking the university student union and browsing on the Internet to find the university bulletin board. The majority of properties are unfurnished, so additional expenditure on furniture should be anticipated. As one is classified as being on an educational exchange, it is possible to register as a student at the university and receive an international student card. The former gives you access to library and sporting facilities and the latter allows you to arrange airline flights with a student discount.

\section{Conclusions}

There is a substantial amount of work involved in moving to the USA. Nonetheless, the advantages are that one may work in a different environment, learning new skills and acquiring habits which may enhance one's clinical practice at home. Investigational facilities are more readily available, with less constraint over the cost of clinical or basic science research, as the university environment is more heavily funded than in Europe. As many interventional and pharmaceutical companies have their headquarters in the USA, it is easier to build relationships and work with leaders in 은 industry to mutual benefit. On a personal note, working in the USA offers a wider view of the world, seeing events through the $N$ American media and experiencing a different political culture. A disadvantage, however, is 尺 that it is more difficult to apply for a consultant job because of the cost of transatlantic travel and the need to spend time at the 0 prospective institution beforehand. Being in $\mathbb{D}$ the USA for a prolonged period before accreditation or CCST may also be to one's disadvantage. The specialist registrar grade $\frac{D}{\mathbb{D}}$ should make this less of a problem for those still in training, as it will afford the security of returning to the grade.

Going to the USA can be a rewarding experience and the trip can be facilitated and costs in terms of time and money minimised by preparing in advance.

NGU was a BHF International Fellow $1995-6$ and NAFC was a BHF International Fellow 1993-5. 


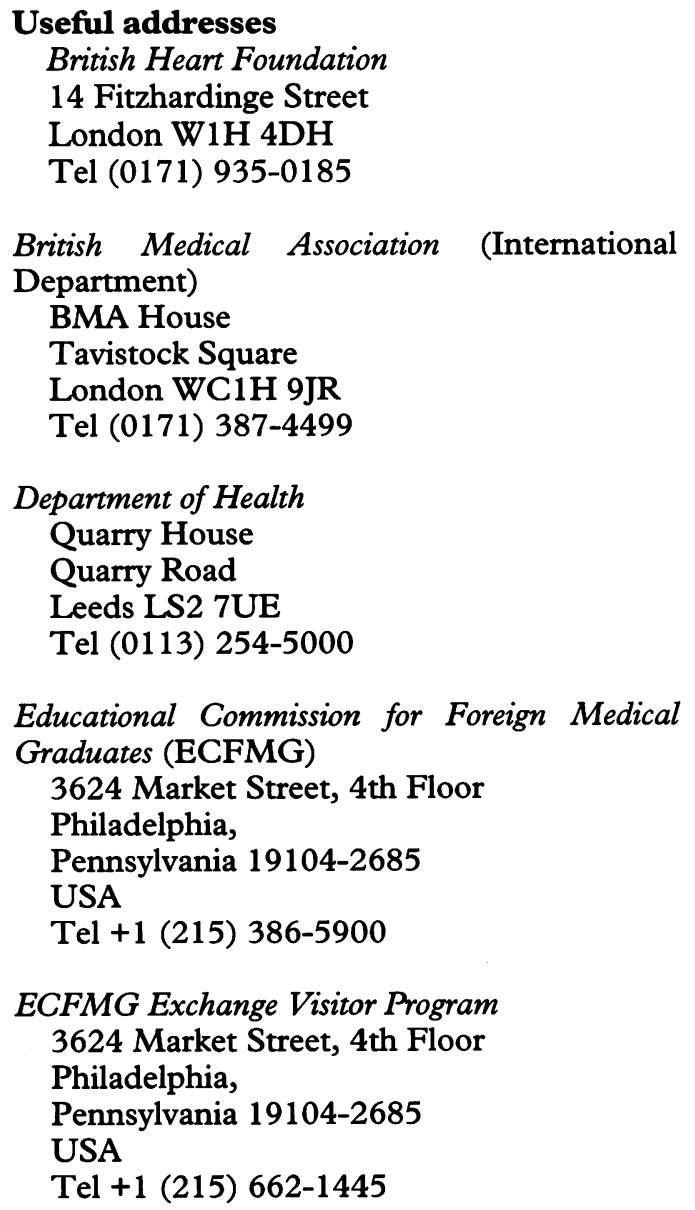

Embassy of the United States of America (Visa Branch)

5 Upper Grosvenor Square

London W1A 2JB

Tel 0891 200290; 0891234229

General Medical Council

Finance Division

178-202 Great Portland Street

London W1N 6JE

Tel (0171) 580-75427

foint Committee on Higher Medical Training

Royal College of Physicians

11 St Andrews Place

Regent's Park

London NW1 4LE

Tel (0171) 935-1174

\section{Medical Research Council}

20 Park Crescent

London W1N 4AL

Tel (0171) 636-54229

Wellcome Trust

181 Euston Road

London NW1 2BE

Tel (0171) 611-8888

1 Hall RJC, Boyle RM, Webb-Peploe M, Chamberlain D, Parker DJ. Guidelines for specialist training in cardiology. Br Heart f 1995;73(suppl 1):1-24.

2 de Bono DP, Gershlick AH, Samani HJ, Garratt CJ. New training guidelines: what are the implications for cardiological research? Heart 1996;75:118-20. 